West German commission

\section{reports on genetic engineering}

\section{Hamburg}

WIDE-ranging recommendations on the applications of genetic engineering are contained in a report of a West German parliamentary commission. Although generally approving the use and exploitation of genetic manipulation, the commission calls for a ban on experiments on fertilized human eggs that have the potential to develop into "complete human individuals" and for a five-year moratorium on the environmental release of genetically transformed microorganisms.

The 400-page report, Chances and Risks of Genetic Engineering, was approved by 16 of the 17 members of the inquiry commission ('Enquete Kommission'), composed of eight experts from industry and science and nine members of parliament (four Christian Democrats, three Social Democrats, one Liberal and one Green). Only the representative of the Greens voted against the report as an example of 'genetic imperialism'.

The report, the result of 55 meetings and 18 hearings, is designed to help the Bundestag to devise new legislation and to inform the public. It applauds the exploitation of genes and the opportunities for more efficient, economic and ecologically beneficial farming. But production of herbicide-resistant plants should be allowed only if the "use is promoted of herbicides that are without ecological or toxicological risk".

The report is not opposed to the application of genetic engineering methods in animal breeding and recommends the "promotion of the use of transgenic animals in biomedical basic research".

More reliable and precise prenatal diagnosis by means of genetic techniques are "welcomed" in the report. But there

\section{Italy participates in new telescope}

THE mysterious fourth partner in the twin 8-m telescope being developed by University of Arizona, Ohio State University and the University of Chicago has been revealed. It is the Italian astronomical community, represented by the Arcetri Astrophysical Observatory in Florence. The Italians will become a full partner in the project. Rather than a cash payment, the Italian contribution will be the fabrication of the telescope, including the mounting, drive and mirror support structure. The binocular telescope, now called the Columbus Project, expects to have first light in 1992, the five hundredth anniversary of Columbus's voyage to the New Land. should be a guarantee that no unacceptable abortion practices will emerge. The "sociological compulsion of abortions of embryos with genetic defects" has to be opposed.

But the screening of newborn babies to recognize treatable diseases is a "worthy instrument of preventive medicine", although screening for untreatable diseases was rejected.

The injection of genetic material into human cells is seen as a "basically acceptable form of therapy", but only if the individual is properly informed by a neutral physician or scientist and if the practice is approved by a special 'committee for biological safety' at the Bundesgesundheitsamt in Berlin.

Experiments on human germ-line cells are to be prohibited even if they are aimed at therapy, "if the germ-line cells can grow into complete human individuals".

\section{Washington}

Although some meteorologists and oceanographers have already declared it so, the US National Weather Service has made it official; an El Niño-Southern Oscillation (ENSO) event is under way.

In a statement on 20 January, the National Weather Service's Climate Analysis Center (CAC) said that December atmospheric and oceanic data from the equatorial Pacific "resemble those of an ENSO warming". CAC's Vernon Kousky says that the weather service delayed calling the event an ENSO episode in part because the expected inversion in the barometric pressures between the island of Tahiti and the city of Darwin in northern Australia had not occurred. But, in December, Tahiti pressure got "quite low", and the Darwin pressure was "quite high", Kousky says, suggesting that the expected seesaw of the Southern Oscillation was indeed taking place.

CAC's model of general ocean circulation indicates that westerly winds in the western equatorial Pacific at the end of 1987 have pushed surface water to the west. This should result in warming of seasurface temperatures along the coast of Peru. Oceanographic data received by Francisco Chavez of Duke University from piers at Paita, Peru, suggest that the warm water has not yet arrived. But Chavez says all predictions are that it will make its appearance "any time now".

If there has been caution about declaring an El Nin̄o to be under way, it is moti-
The "guidelines for protection from dangers through in vitro recombined nucleic acids", created for use in gene laboratories, must be adopted in all production processes, in particular genetic work with retroviruses, cell fusion and hybrid cells. The release of genetically transformed microorganisms must be stopped for five years and this moratorium should be used for risk analysis and further research into possible ecological dangers. The release of viruses into the environment is prohibited with the exception of vaccines for humans and animals.

Generally, the commission emphasized that the existing guidelines (see Nature 317, 469; 1985) have proved efficient even though they are voluntary, but they should be made legally binding.

Only the Greens opposed the use of the new techniques. The commission agreed that their dissenting opinion should be added to the report. The Greens warned of the "ability of humans to manipulate humans" and rejected the placing of "resources of nature in private hands".

Jurgen Neffe

\title{
US weather service makes threat of EI Niño official at last
}

vated in part by the hysteria that has accompanied past announcements. The ENSO event in $1982-83$, by all accounts much stronger than the present episode, was blamed for extreme weather conditions and millions of dollars in damage.

Kousky's estimates for the impact of the current event are much less severe. He says wetter than normal conditions along the coast of the Gulf of Mexico can be blamed on El Niño, as can be unseasonably warm temperatures in the northern sections of the United States. He adds that northern Australia and southern Africa have been somewhat drier than normal, while eastern equatorial Africa is wetter. By later this month, the warm coastal waters should bring heavy rains to northern Peru. Chavez says rainfall in the region is already slightly above normal.

Warm sea-surface temperatures and wind patterns in the equatorial Pacific have convinced many that an ENSO event was either taking place or imminent (see Nature 324, 504; 1986). Tim Barnett of Scripps Institute of Oceanography says Pacific sea-surface temperatures should decline slowly over the next six months and that even if this year's event is smaller than that in 1982-83, it is still noteworthy. Many were convinced as long ago as the end of last summer that an ENSO episode would occur. Barnett believes that models must take into account phenomena of low frequency - of the order of two to seven years - to be successful.

Joseph Palca 